Article

\title{
Learning Strategies at a Higher Taxonomic Level in Primary Education Students in the Digital Age
}

\author{
Margarita Aravena ${ }^{1}$, María Natalia Campos-Soto ${ }^{2, *(1)}$ and Carmen Rodríguez-Jiménez ${ }^{2}$ (D) \\ 1 Postgraduate Academic of the Faculty of Education and Social Sciences, University of Andrés Bello, \\ Republica 470 piso 1, Santiago 8370227, Chile; marg.aravena@uandresbello.edu \\ 2 Department of Didactics and School Organization, University of Granada, 18010 Granada, Spain; \\ carmenrj@ugr.es \\ * Correspondence: ncampos@ugr.es
}

Received: 30 September 2020; Accepted: 23 November 2020; Published: 26 November 2020

\begin{abstract}
The education system must respond to the demands and needs of today's society. To meet this demand, teachers must identify the degree of cognitive skills that our students possess through digital learning strategies that encourage the development of these superior skills because of the impact of technological resources on student motivation. To carry out this assessment, two types of strategy tests were applied to evaluate cognitive skills, one determining the student's ability to create an opinion of their own based on ideas and visions of other authors (perspective analysis) and the other strategy test to distinguish the main elements of an information, identifying a general pattern (abstraction), which were reviewed with a task performance instrument (rubrics). A mixed methodology was used through a case study, with a selected and intentional sample of 34 students of the Primary Education Grade. The results show that elaborating questions that go deeper into a topic and labelling contents is not an easy task and that abstraction is one of the most complex skills to develop in students. It should be noted that, in practically all areas, men's averages exceed those of women. Finally, the use of digital strategies must be incorporated as permanent routines and the relationship between technology and pedagogy allows for the management of learning and therefore increases higher level cognitive abilities.
\end{abstract}

Keywords: higher thinking; cognitive skills; perspective analysis; abstraction; ICT; digital

\section{Introduction}

If there is something that characterizes the society of the 21st century, it is the excessive load of information that we receive from numerous sources, mainly from the media; that is why, in the educational field, it is necessary to develop logical and abstract processes in students that allow them to acquire and reconstruct knowledge, with the objective of developing the necessary skills to know how to manage successfully in a world in which competitiveness prevails [1].

Developing skills at a higher taxonomic level during the training process in students who are trained in a specific knowledge area is one of the greatest challenges faced by universities at an international level $[2,3]$, taking into account that we are facing a rapid expansion of students enrolled in Higher Education with heterogeneous profiles [4-6], a situation that is being accentuated by the evolution that current societies are experiencing, which are betting on an economy based on knowledge and globalization $[7,8]$.

The idea of establishing a skill classification system came from Benjamin Bloom in 1948 [9]. The objective was to have a common document that would facilitate interaction between examiners, promoting the exchange of ideas on how to perform the assessment, types of examinations and sharing resources to perform the assessment. To this end, a "Taxonomy of Learning Domains" was developed, 
known as "Bloom's Taxonomy", which is identified as "The Objectives of the Learning Process", that is, the knowledge and skills that learners must have acquired after going through a learning process [10].

More and more professionals are betting on the development of higher thinking skills [9], that is, the ability to interrelate the information stored in our memory with the information that reaches us newly, acquire a deep understanding of it and be able to apply it to different contexts $[11,12]$ with the aim of finding solutions to complex problems that may arise [13]. An effective teacher, in addition to having the required knowledge, must have the ability to unravel what their students think and believe and how they accommodate new information [6].

Achieving the highest taxonomic level is possible through the application of strategies that encourage the development of superior thinking skills. This is a commitment that universities in today's society must assume [7], and teachers must be prepared for it. The development of thinking skills depends on all professionals involved in the teaching and learning process [14]. Likewise, it is essential to know the characteristics of these students in order to define the strategies and actions that must be carried out to guarantee their permanence [15].

Within these strategies, we find the use of technological resources that encourage the development of these superior skills, because of the impact they generate in the motivation of students [16-18]. However, "research indicates that the pedagogies necessary for the effective integration of educational technologies are not yet evident among most teachers" [19] (p. 367). The study [6] indicates three main aspects that teachers must address: connection between students and teachers, interaction and collaboration between both parties by adapting the teaching process to the characteristics and needs of the learners, and feedback from students.

Following [20], learning is a system of interacting processes that include five types of thinking represented in five dimensions of learning. These dimensions refer to a complex model in order to define and respond to the student learning process and are as follows: Dimension 1: Attitudes and perceptions; Dimension 2: Acquiring and integrating knowledge; Dimension 3: Extending and refining knowledge; Dimension 4: Meaningful use of knowledge; Dimension 5: Mental habits.

However, learning does not end with the acquisition and integration of knowledge but, as a result, students develop a better understanding through the refinement of their knowledge, that is, they come to identify different perspectives that will help them to seek and apply solutions to mistakes made and reflect on their experiences, drawing conclusions that will help them with future situations [20]. Some of the reasoning processes that students use to extend and refine knowledge are: comparison, classification, inductive reasoning, deductive reasoning, support construction, error analysis, abstraction and perspective analysis [21].

In accordance with the objective of this study, we will focus on the last two reasoning processes: abstraction processes and perspective analysis.

\subsection{Perspective Analysis}

Perspective analysis is defined as the process in which students have the ability to examine and compare different positions on the same issue and understand the various reasons behind them in order to arrive at an opinion or position of their own [20].

Perspective analysis is an intellectual skill that helps us understand that all perspectives, both our own and others', have their share of truth because it teaches us how to contrast our opinions by comparing them with those of others [22] According to [23], it is important to teach students to analyze perspectives because it helps us to know others better and to know ourselves more deeply, while respecting the ideas of others.

There is no standardized model for this process [24], but experience suggests that the following steps should be taken: examine the information as a whole and identify the main idea of the text, note the opinions expressed in reference to the central idea, and differentiate between facts and opinions [20]. 
To sum up, we can say that a perspective analysis will help us to be critical, to form our own opinion, to respect what others think and to base our thinking.

\subsection{Abstraction}

Abstraction is understood as the process that builds on the student's ability to identify patterns [25]. Recognizing these patterns is essential in order to respond effectively to the different stimuli that bombard us in a world saturated with information [26]. Abstraction allows us to organize and use that information with alacrity [20]. In this line, [27] states that abstract thinking offers the possibility of changing from one position to another voluntarily, dividing the whole into certain parts and analyzing different perspectives of the same situation.

According to [28], abstraction focuses on two aspects: the suppression of unnecessary information and the generalization of content and the search for patterns. The difficulty in developing it lies in the fact that students have divergences in order to achieve it, because abstraction is in itself an abstract process [29].

The application of abstract processes ensures the promotion of reasoning skills and the development of meaningful thinking $[1,30]$. If there is something that characterizes abstract thinking, it is the speed, which our cognitive capacities operate with [31]. Abstract thinking processes have already been studied by well-known philosophers such as Pythagoras, Plato, Parmenides, Aristotle, among others. This type of thinking reflects the world in a fuller and deeper way, constituting the most complex form of knowledge [32]. According to [33], formal or abstract thinking begins around the age of 11 and settles down at approximately 15 years old.

"In the process of abstraction, thought is not limited to highlighting and isolating some property and relationship of the object accessible to the senses ..., but it tries to discover the hidden and unreachable nexus to empirical knowledge" [34] (p. 106).

Abstraction is a very powerful tool to extend and refine knowledge as it allows students to relate content that seems different. This makes students analyze differences and similarities between concepts they are studying by helping them recognize similar patterns between unknown information and information that is familiar to [20]. Based on the above, [20] propose different activities that can be carried out in class to develop abstraction skills:

1. "Help students understand the process of abstraction". We will begin the process by presenting the student with content that is familiar to them; then we will show them content that is unfamiliar, ask them to identify similarities and, from there, to make connections.

2. "Give students a model for the process of abstraction and create opportunities for them to practice using the process". After providing the students with the steps to follow to carry out the process of abstraction we will give them specific information, then we will express our opinion about it and, finally, they will have to be the ones to carry out the abstraction of this information from the given model.

3. "As students study and use the process of abstraction, help them to focus on the critical steps and difficult aspects of the process". Three key points will be considered: identification of the literal information, translation from the literal to the abstract, and making connections.

4. "Provide students with graphic organizers or representations to help them understand and use the process of abstraction". The graphic organizer will be divided into three parts: two will record the literal information of the contents that are associated and the third will record the abstract pattern that connects them.

5. "Use tasks structured by the teacher and structured by the students". The teacher will provide information to the students and follow their steps. As the students become more fluent in the process of abstraction, they will be given more freedom to structure the task themselves. The teacher will have to supervise them while they work but gradually increase their freedom so that they feel more and more confident at each step of the process. 
Bearing in mind that we are in the digital age, these activities could be carried out through technological resources, which, as we mentioned before, encourage the motivation of students. By way of example, it is worth highlighting Storyboard to carry out activity four. Storyboard is a graphic organizer, a novel way of visually presenting certain information [35]. On the other hand, the application of Cmaptool, a tool that teachers can use to make analysis of perspectives by means of videos of different themes, to show the positions through graphic organizers; on the other hand, the Word processor, which gives the option of counting words to make summaries, decreasing the characters without losing the central ideas, are simple tasks that manage to increase the abstraction skill. Therefore, it is the teacher who must consider different digital resources and become aware of the skills he or she wants to develop in order to select the most relevant ones when joining digital and cognition.

Technologies are advancing rapidly, becoming a growing trend in education, fostering the development of problem-solving skills, collaborative work, critical thinking and even the resolution of complex social dilemmas [36].

All educational institutions should consider the development of higher thinking skills as one of their strategic objectives, in line with UNESCO's competencies for the 21st century [2,5].

\section{Materials and Methods}

\subsection{Population and Sample}

A mixed study with a descriptive design was implemented on a non-probabilistic sample, selected for convenience, and a validated strategy test [1] was applied to 34 students of the Primary Education Teaching Degree of the University of Granada, during the 2019/20 academic year, asynchronously via google form. The students are all Spanish nationals and are in their second academic semester. The distribution of the sample is shown in the following table (Table 1):

Table 1. Sample distribution.

\begin{tabular}{ccc}
\hline Sex & Sample Frequency & Percentage Distribution \\
\hline Male & 11 & $32 \%$ \\
Female & 23 & $68 \%$ \\
\hline
\end{tabular}

The sample consists of 34 people, 23 women (68\%) and 11 men (32\%), a very common trend in educational qualifications, where the presence of women is usually much higher than that of men. The age range fluctuates between 19 and 28 years, with the average age being 20 years.

The sampling was for convenience, following the criteria of access and availability of the respondents. It is necessary to mention that there are other studies that have used small samples $[17,18,37,38]$; what is relevant are the results and conclusions that have emerged to continue research and move towards a collective construction of knowledge.

\subsection{Instruments}

The test evaluates two skills: perspective analysis and abstraction. The first part gives two authors' definitions of critical thinking, in which the student is asked to analyze each position independently. When developing the perspective analysis, they should do it in their own words, use synonyms, and not copy the textual words of the text. In this part of the test the student describes the opinions of others and his/her own perspective on the subject, i.e., evidence of perspective analysis.

In the second part of the test, they must make a synthesis for each perspective, that is, reduce the content, and leave the essence of the analyzed text, without losing the central idea.

They must create a general title on the subject in question and synthesize the ideas of the two authors worked on previously and the position they themselves have developed. They must then formulate questions, which should not be literal, but rather create a question for each perspective with the aim of broadening the subject matter addressed. Finally, they must label, that is, put a 
brief title, of two or three words, that transmits the main part of the content. In this part of the test, they demonstrate the ability to suppress meaning by carrying out each of the actions mentioned above, therefore, in the end, managing to give meaning to the definition by means of labelling.

The method that was implemented was initially to download the answers from the form, then proceeded to analyze the tests qualitatively by means of criteria, which have four levels of execution $(4,3,2,1)$ to measure the capacity of perspective and abstraction of the students. Then, a database was created in the Excel program by variables that includes each of the strategy tests, to make a descriptive analysis with the SPSS program and correlate the gender variables of the test.

\section{Results}

This section describes the results of the strategy tests, which have been analyzed from two perspectives, quantitative and qualitative.

\subsection{Perspective Analysis}

Within this analysis of perspectives, three different categories are presented and analyzed through a heading with four levels of assessment, these are: Optimal, Good, Satisfactory and Deficient.

The following table (Table 2) shows the different perspectives with the different results obtained

Table 2. Sample distribution.

\begin{tabular}{cccc}
\hline Levels & Author 1 Perspective & Author 2 Perspective & Personal Perspective \\
\hline Optimal & 19 & 14 & 20 \\
Good & 6 & 12 & 6 \\
Satisfactory & 6 & 5 & 6 \\
Deficient & 3 & 3 & 2 \\
\hline Total & 34 & 34 & 34 \\
\hline
\end{tabular}

With regard to author's perspective 1, 19 students obtained the optimal level, that is, these students were able to understand and identify the author's ideas; on the other hand, in the good and satisfactory levels, six students obtained these levels respectively in each one; however, only three students have obtained scores regarding the deficient level. Author 1's delivered definition of critical thinking is reflected in the score obtained, i.e., they were able to use synonyms and use their own words.

Following the same line, in the author's perspective category 2, the results are disparate. At the optimal level, 14 students obtained this level, followed by the good level with 12 members. On the other hand, in the case of the deficit level, again three students were evaluated in this level, that is, they used the same words of the author and were not able to contribute with the author's point of view using original words.

As far as the personal perspective is concerned, the results are more positive. A total of 20 people obtained the optimal level and only 2 students were evaluated in the deficit level, that is, they were not able to elaborate an idea with the authors' points of view. Generally, when students analyze two or more perspectives, they undoubtedly improve their own view of a topic, that is, they manage to integrate visions of others in order to elaborate their own construction.

At the optimum level, considering both perspectives, it was found that they concentrate the best results of the sample; although the perspective of Author 1 ( $55.9 \%$ of the sample) predominates at this level, as opposed to the perspective of Author $2(41.17 \%)$.

In general, the results show how the students of the Primary Education degree have a good development of the capacity to analyze the positions of the authors and to contribute with their own vision of critical thinking based on both definitions; however, those in the deficit level made a literal copy of the positions of the authors. In short, these students require more practice in this strategy and feedback. 


\subsection{Abstraction}

In this second part of the test, three categories of analysis are established: synthesis, question creation and labelling.

With regard to the synthesis category, Table 3 shows the results of the participants. It is possible to extract with these results that it is within the subcategory of author 1 where there is a greater number of students who have obtained a deficient level in terms of not managing to synthesize with their own words the ideas of the text of this author. On the contrary, it is the own synthesis that obtains better results at the optimal level, the students that have managed to synthesize all the information being 18 . If we compare the data, author 1's synthesis has $26.4 \%$ in the satisfactory level and $14.7 \%$ in deficient, that is to say, there is a greater percentage of students who do not manage to synthesize this definition.

Table 3. Summary of content. Distribution.

\begin{tabular}{cccc}
\hline \multicolumn{4}{c}{ Summary } \\
\hline Levels & Author 1 & Author 2 & Own \\
\hline Optimal & 15 & 12 & 18 \\
Good & 5 & 15 & 8 \\
Satisfactory & 9 & 4 & 5 \\
Deficient & 5 & 3 & 3 \\
Total & 34 & 34 & 34 \\
\hline
\end{tabular}

The creation of questions is the next category analyzed. Thus, it is necessary to emphasize that the questions must be related to the reduction of the content and focus on the main aspects of the text. This category is, on a general level, the one with the worst results, as it can be seen in Table 4 . The highest values are concentrated in the central levels (good and satisfactory), while the optimal level is only reached by four students for author 1, five students for author 2 and six students for own question. Likewise, the deficit level is the one that obtains the highest values when compared to the same level in the other categories within the abstraction. Students tend to ask literal questions that are easier to elaborate on than questions that go deeper into a topic.

Table 4. Ask questions. Distribution.

\begin{tabular}{cccc}
\hline \multicolumn{4}{c}{ Ask Questions } \\
\hline & Author 1 & Author 2 & Own \\
\hline Levels & Question & Question & Question \\
\hline Optimal & 4 & 5 & 6 \\
Good & 12 & 12 & 10 \\
Satisfactory & 11 & 11 & 7 \\
Deficient & 7 & 6 & 11 \\
Total & 34 & 34 & 34 \\
\hline
\end{tabular}

Although at the optimal level in both perspectives the results were not as expected; when observing the results in the Good and Satisfactory levels, both in perspective 1 and 2, it can be stated that in general the students are able to create questions according to the given parameters. (67.6\%). However, the result obtained in the deficit level of the question itself (32.35\% of the sample) is very striking.

Finally, in the creation of questions (Table 5), the percentage of students who achieve the optimal level is low; in general, the great majority develop literal questions on critical thinking. The highest levels are those corresponding to "satisfactory" in all subcategories, which means that students do not manage to abstract the essential ideas of the definition, a product that this description has unusual and familiar vocabulary for the student. One aspect to highlight is that this category of abstraction is the one that gets the lowest levels within the deficit level, which means that most students are not able to create 
titles that contain essential elements of the content in three words. That is to say, they do not manage to abstract the definitions of the authors and their own interpretation of critical thinking, being reflected in the labelling, that they do not have this ability developed. This is reflected in perspective 1, 2 and in the own one, with the low percentages achieved in Optimal (29.4\% and 32.3\%).

Table 5. Label. Distribution of the sample.

\begin{tabular}{cccc}
\hline \multicolumn{3}{c}{ Label } \\
\hline Levels & Author 1 & Author 2 & Own \\
\hline Optimal & 10 & 10 & 11 \\
Good & 2 & 9 & 3 \\
Satisfactory & 21 & 14 & 15 \\
Deficient & 1 & 1 & 5 \\
Total & 34 & 34 & 34 \\
\hline
\end{tabular}

\subsection{Comparison by Sex between Study Categories}

In this point, the results obtained after comparing, between sexes, the different categories of analysis concerning the analysis of perspectives and abstraction are shown (Table 6).

Table 6. Sex comparison.

\begin{tabular}{|c|c|c|c|c|c|c|c|}
\hline \multicolumn{8}{|c|}{ T de Student } \\
\hline Area & Sex & $\mathbf{N}$ & Media & SD & $\mathbf{t}$ & gl & $p$-Value * \\
\hline \multirow{2}{*}{ Perspective 1} & $\mathrm{~F}$ & 23 & 3.04 & 1.107 & \multirow{2}{*}{-1.335} & \multirow{2}{*}{32} & \multirow{2}{*}{0.191} \\
\hline & $\mathrm{M}$ & 11 & 3.55 & 0.820 & & & \\
\hline \multirow{2}{*}{ Perspective 2} & $\mathrm{~F}$ & 23 & 2.96 & 1.022 & \multirow{2}{*}{-1.157} & \multirow{2}{*}{32} & \multirow{2}{*}{0.256} \\
\hline & $\mathrm{M}$ & 11 & 3.36 & 0.809 & & & \\
\hline \multirow{2}{*}{ Own Perspective } & $\mathrm{F}$ & 23 & 3.17 & 1.029 & \multirow{2}{*}{-1.046} & \multirow[b]{2}{*}{32} & \multirow{2}{*}{0.303} \\
\hline & $\mathrm{M}$ & 11 & 3.55 & 0.820 & & & \\
\hline \multirow{2}{*}{ Summary Author 1} & $\mathrm{~F}$ & 23 & 2.74 & 1.176 & \multirow{2}{*}{-1.053} & \multirow{2}{*}{32} & \multirow{2}{*}{0.300} \\
\hline & $\mathrm{M}$ & 11 & 3.18 & 1.079 & & & \\
\hline \multirow{2}{*}{ Summary Author 2} & $\mathrm{~F}$ & 23 & 2.96 & 0.928 & \multirow{2}{*}{-0.937} & \multirow{2}{*}{32} & \multirow{2}{*}{0.356} \\
\hline & $\mathrm{M}$ & 11 & 3.27 & 0.905 & & & \\
\hline \multirow{2}{*}{ Own perspective synthesis } & $\mathrm{F}$ & 23 & 3.04 & 1.022 & \multirow{2}{*}{-1.376} & \multirow{2}{*}{32} & \multirow{2}{*}{0.178} \\
\hline & $\mathrm{M}$ & 11 & 3.55 & 0.934 & & & \\
\hline \multirow{2}{*}{ Questions Author 1} & $\mathrm{~F}$ & 23 & 2.22 & 0.998 & \multirow{2}{*}{-1.484} & \multirow{2}{*}{32} & \multirow{2}{*}{0.147} \\
\hline & $\mathrm{M}$ & 11 & 2.73 & 0.786 & & & \\
\hline \multirow{2}{*}{ Questions Author 2} & $\mathrm{~F}$ & 23 & 2.35 & 1.027 & \multirow{2}{*}{-1.080} & \multirow{2}{*}{32} & \\
\hline & $\mathrm{M}$ & 11 & 2.73 & 0.786 & & & 0.288 \\
\hline Own Persnective Ouestions & $\mathrm{F}$ & 23 & 2.39 & 1.158 & 0.504 & 32 & 0618 \\
\hline Uwil rerspective Questions & $\mathrm{M}$ & 11 & 2.18 & 1.079 & -0.504 & 32 & 0.618 \\
\hline Jahel Author 1 & $\mathrm{~F}$ & 23 & 2.57 & 0.945 & & 32 & 0650 \\
\hline Label Author 1 & $\mathrm{M}$ & 11 & 2.73 & 1.009 & -0.458 & 32 & 0.650 \\
\hline & $\mathrm{F}$ & 23 & 2.87 & 0.920 & & & \\
\hline Label Author 2 & $\mathrm{M}$ & 11 & 2.73 & 0.905 & 0.424 & 32 & $0.6 / 4$ \\
\hline & $\mathrm{F}$ & 23 & 2.70 & 1.105 & & & \\
\hline Label Own Perspective & $\mathrm{M}$ & 11 & 2.36 & 1.120 & 0.816 & 32 & 0.420 \\
\hline
\end{tabular}

In this table, if we look at the level of bilateral significance, we can see that there are no significant differences in any of the cases, since all the values exceed 0.05 . However, trends are found with respect to sex; that is, in practically all areas the averages for men are higher than those for women are. Only in the areas of asking questions about one's own perspective, labelling author 2 and labelling one's own perspective are women's averages higher than men's are.

Similarly, it can be seen how the values fluctuate with respect to the average in a homogeneous way (SD) in both sexes. 


\section{Discussion and Conclusions}

Developing higher thinking skills should be one of the objectives of all educational institutions, taking into account the competencies set by UNESCO for the 21st century $[2,5]$ along with the use of technology as a regular tool for generating skills, through digital strategies.

From the above, the interest in carrying out this study arises, in order to check the level presented by students in the Primary Education Degree in relation to the perspective of analysis and the process of abstraction.

With regard to the analytical perspective, the results show that most of the participants present an optimal level, that is, they have very well acquired their capacity to analyze the positions of various authors, contributing critical thinking based on their definitions, in line with other research [22,23]. These results are similar to those obtained in research in Chile [2] and Spain [39]; this means that the ability to analyze other people's positions is achieved without major cognitive problems.

With regard to the synthesis category, it should be noted that the greatest number of students (5) are in the deficit level with respect to author 1, since they have not managed to synthesize the ideas in the text in their own words. On the contrary, most of the participants (18) in the synthesis itself is where they have obtained optimal results, managing to synthesize all the information, coinciding with $[25,27,29]$.

In the creation of questions, one aspect to highlight is that this category of abstraction is the one that obtains the lowest levels within the deficit level, which means that most students are not able to create titles that contain essential elements of the content in three words, according to [20].

Finally, and taking into account the level of bilateral significance, it can be seen that there are no significant differences in any of the cases. However, gender-related trends are found; that is, in practically all areas men's averages are higher than women's are. Only in the areas related to asking questions about one's perspective, labelling in author 2 and labelling one's perspective are women's averages higher than men's are. $64.0 \%$ of men have the ability to look ahead and women $60.9 \%$. In the ability of abstraction, men achieve $27.3 \%$ and women $26.1 \%$.

In the capacity of synthesis, to manage to elaborate a better synthesis of the text in its own perspective at the optimal level, on the contrary in the synthesis author 1, there are 14 students classified in the concepts of satisfactory and deficient.

Authors such as [40], focus on strategies to increase the ability of abstraction, which is why teachers must implement actions to develop it both inside and outside the classroom. A concrete example is the elaboration of summaries in 300 words that can be asked to the students, then, to be diminishing to 200 and finally, the same summary to leave it in 100 words, with the purpose of extracting the essential of the text. Another effective strategy is the labelling of the content [41], which can be worked on in paragraphs, so that the synthesized ideas of the text are expressed in one, two, or even three words.

In summary, we can say that a perspective analysis will help us to be critical, to form our own opinion, to respect what others think and to base our thinking. This process is one of the most powerful of thought since it requires great skill and discipline to make a reflection on a particular content from the opinion of oneself and others. Likewise, abstraction is a very powerful tool to extend and refine knowledge since it allows students to relate contents that seem different, analyze differences and similarities between concepts they are studying, helping them to recognize similar patterns between unknown information and information that is familiar to them [20]. It should be noted that abstraction is one of the most complex skills to develop in students, so further work should be done on the subject in question and use free programs, such as: cmaptool, to elaborate concept maps, word cloud, to capture group ideas to demonstrate abstract ability and GoConqr, to elaborate mind maps to extend knowledge, among others. In the case of video games of action, sports, science, history, among others, several studies highlight them as a way of generating learning, solving problems and developing logical thinking $[17,18,38]$. Abstraction can also be worked on, students can analyze what the video game is about, and then synthesize the essence of the contributions it delivers, then they can ask questions that go deeper into the subject and finally, in a word, label the essence of the video game. 
Finally, the use of digital strategies must be incorporated as common practice within the learning process. Because of the pandemic, it has become evident that technology is necessary to work in a synchronous and asynchronous manner and, finally, teaching can be provided both in the classroom and virtually. In other words, the digital era, if it had already transformed the way of teaching and learning, today a reality has come to be established above all in times of crisis.

One of the limitations of this study is the application of the test to a small sample; however, these results are the starting point for further implementation of the test in other careers in education and other disciplines, in order to generate knowledge in this area and design strategies to develop thinking with the use of digital media or others.

Author Contributions: Conceptualization, M.A.; methodology, M.A. and C.R.-J.; software, C.R.-J.; validation, M.A. and M.N.C.-S.; formal analysis, C.R.-J.; investigation, M.N.C.-S.; resources, M.A.; data curation, C.R.-J.; writing-original draft preparation, M.N.C.-S.; writing—review and editing, C.R.-J. and M.N.C.-S.; visualization, M.N.C.-S.; supervision, M.A. All authors have read and agreed to the published version of the manuscript.

Funding: This research received no external funding.

Conflicts of Interest: The authors declare no conflict of interest.

\section{References}

1. Jaramillo-Naranjo, L.M.; Puga-Peña, L.A. El pensamiento lógico-abstracto como sustento para potenciar los procesos cognitivos en la educación. Colección De Filos. De La Educ. 2016, 21, 31-51. [CrossRef]

2. Araneda-Guirriman, C.; Aravena, M.; Cortes, T.; El Homrani, M. New profile of the university student and his/her thinking strategies: Evidence from Chile. In Proceedings of the 12th Annual International Conference of Education, Research and Innovation, Seville, Spain, 11-13 November 2019; ISBN 978-84-09-14755-7.

3. Ahmed, K. Teaching critical thinking and writing in higher education: An action research Project. TEAN J. 2018, 10, 74-84.

4. Teixeira, P.; Landoni, P. The rise of private higher education. In Rethinking the Public-Private Mix in Higher Education; SensePublishers: Rotterdam, The Netherlands, 2017; Volume 21, pp. 243-280.

5. Ossa-Cornejo, C.; Lepe-Martínez, N.; Díaz-Mujica, A.; Merino-Escobar, J.; Larraín-Sutil, A. Programas de pensamiento crítico en la formación de docentes iberoamericanos. Profesorado 2018, 22, 443-462. [CrossRef]

6. Correira, R.; Navarrete, G. Social Cognition and Executive Functions as Key Factors for Effective Pedagogy in Higher Education. Front. Psychol. 2017, 8, 1-5. [CrossRef]

7. Araneda-Guirriman, C.; Pedraja-Rejas, L. Las universidades y el nuevo perfil de estudiantes: Nuevas realidades y retos para América Latina. Interciencia 2017, 42, 786-788.

8. Espinoza, O.; González, L. Access of Disadvantaged Students to Higher Education in Chile: Current Scenarios and Challenges. In Bridges, Pathways and Transitions; Shah, M., Whiteford, G., Eds.; Pathways and Transitions: Oxford, UK, 2017; pp. 103-126. [CrossRef]

9. González-Murillo, L.A.; Cárdenas-Galindo, J.A.; Arellano-Gónzález, J.C. Desarrollo de habilidades del pensamiento de orden superior a través de actitudes de desempeño. Rev. Electrónica Anfei Digit. 2017, 6, 1-9.

10. Jensen, J.L.; McDaniel, M.A.; Woodard, S.M.; Kummer, T.A. Teaching to the test... or testing to teach: Exams requiring higher order thinking skills encourage greater conceptual understanding. Educ. Psychol. Rev. 2014, 26, 307-329. [CrossRef]

11. Murray, J.W. Pensamiento y metacognición de orden superior en el aula de educación básica de primer año: Un estudio de caso sobre el uso de borradores codificados por colores. Open Rev. Educ. Res. 2014, 1, 56-69. [CrossRef]

12. Icfes. Resultados Prueba Pirls. 2011. Available online: http://www.icfes.gov.co/investigacion/evaluacionesinternacionales/pirls (accessed on 24 June 2020).

13. López, J.; Whittington, M.S. Higher-order thinking in a college course: A case study. NACTA J. 2014, $58,74-81$.

14. García-Castañeda, M.; Gómez de Castro, J. Desde la didáctica no parametral ... Estrategia pedagógica para desarrollar el pensamiento crítico. Rev. Educ. Y Humanismo 2015, 17, 186-201. [CrossRef] 
15. Araneda-Guirriman, C.; Gairín, J.; Pedraja-Rejas, L.; Rodríguez-Ponce, E. Percepciones sobre el perfil del estudiante universitario en el contexto de la educación superior de masas: Aproximaciones desde Chile. Interciencia 2018, 43, 864-870.

16. Montes, A.H.; Vallejo, A.P. Efectos de un programa educativo basado en el uso de las TIC sobre el rendimiento académico y la motivación del alumnado en la asignatura de Tecnología de Educación Secundaria. Educ. XX1 2016, 19, 229-250.

17. Brazo Millán, A.I.; Muñoz González, J.M.; Castro de Castro, C. Learning lexicon and French spelling at university through the SCRIBBLENAUTS video game. EDMETIC 2018, 7, 18-36. [CrossRef]

18. Morales, M. Viability of the use of the video game in the classroom: Practical opinions of pre-service teachers. EDMETIC 2018, 7, 78-91. [CrossRef]

19. Prestidge, S. Examining the shaping of teachers'pedagogical orientation for the use of technology. Technol. Pedagog. Educ. 2017, 26, 367-381. [CrossRef]

20. Marzano, R.J.; Pickering, D.J. Dimensiones del Aprendizaje. Manual Para el Maestro; ITESO: Jalisco, Mexico, 2005; pp. 1-354.

21. Masapanta, S.; Velázquez-Iturbide, J.A. Primeros pasos para una mejora en el uso de la taxonomía de Bloom en la enseñanza de la informática. Rev. Iberoam. De Inf. Educ. 2017, 26, 1-12.

22. Bermeosolo, J. Cómo Aprenden Los Seres Humanos: Una Aproximación Psicopedagógica; Ediciones Universidad Católica de Chile: Santiago, Chile, 2013; p. 444. ISBN 978-956-14-1368-9.

23. Martínez, R.M.; Tardelli, E.R. Estudo de caso sobre o uso da taxonomia de Bloom aplicada a ferramentas virtuais no ensino superior. Rev. Bras. de Ensino Super. 2018, 4, 7-20. [CrossRef]

24. Gibbs, G. How assessment frames student learning. In Innovative Assessment in Higher Education, 2nd ed.; Routledge: London, UK, 2019; pp. 43-56. ISBN 9781138581197.

25. Bennedsen, J.; Caspersen, M.E. Abstraction ability as an indicator of success for learning object-oriented programming? ACM SIGCSE Bull. 2014, 38, 1-5. [CrossRef]

26. Darwish, A. The abstract thinking levels of the science-education students in Gaza universities. Asia Pac. Forum Sci. Learn. Teach. 2014, 15, 1-24.

27. Rojas, J. El pensamiento Abstracto a partir de la interdisciplinariedad de las Matemáticas. La Educación Matemática como Herramienta en el Desempeño Profesional Docente. Eco Matemático 2017, 8, 51-53. [CrossRef]

28. Tapasco, S.M. Research and experimentation in the development of abstract thought: An analysis. RACCIS 2017, 7, 36-45.

29. Soca, E.B. Design of the dynamic and interactive course for the teaching learning process of the theme. Bases for the development of abstract thinking and logical reasoning. Rev. Cuba. De Inf. Médica 2017, 9, $18-29$.

30. Yanes, J.R. Pensamiento complejo abstracto en el aula. Sophia 2016, 21, 121-141. [CrossRef]

31. Ferreira, H.; Pedrazzi, G. Teorías y Enfoques Psicoeducativos de Aprendizaje; Novedud: Buenos Aires, Argentina, 2007.

32. Andonegui, M. El Desarrollo Del Pensamiento Lógico; Colección Procesos Educativos: Caracas, Venezuela, 2009; p. 101.

33. Piaget, J. Teoría Del Desarrollo Cognitivo; Morata: Madrid, España, 1980.

34. Ruiz-Limón, R. Historia De La Ciencia Y El Método Científico; Edición Electrónica: Atlanta, GA, USA, 2006; ISBN 978-84-690-6815-1.

35. Sánchez-Carrero, J. Introducción a la educación mediática infantil: El diseño del Storyboard. Rev. De La Seeci 2011, 24, 107-124. [CrossRef]

36. Adams Becker, S.; Cummins, M.; Davis, A.; Freeman, A.; Hall Giesinger, C.; Ananthanarayanan, V. NMC Horizon Report: 2017 Higher Education Edition; The New Media Consortium: Austin, TX, USA, 2017.

37. Del Moral, M.; Fernández, L. Video games in the classrooms: Implications of a disruptive innovation to develop the Multiple Intelligences. Rev. Complut. De Educ. 2015, 27, 97-118. [CrossRef]

38. Soto-Ardila, L.M.; Melo, L.; Caballero, A.; Luengo, R. Estudio de las opiniones de los futuros maestros sobre el uso de los videojuegos como recurso didáctico a través de un análisis cualitativo. Rev. Ibérica Sistem. Técn. Inf. 2019, 33, 48-63.

39. Aravena, M.; Pozo-Sánchez, S.; Santos-Villalba, M.J.; Campos-Soto, M.N. Habilidades del Pensamiento Superior en Estudiantes de Máster: Estudio de caso en la Universidad de Granada; Congress Proceedings Book Innovagogía: Seville, Spain, 2020; p. 284, ISBN 978-84-09-03214-3. 
40. Serna, E. La abstracción como componente crítico de la formación en ciencias computacionales. Rev. Av. En Sist. E Inf. 2013, 8, 79-83.

41. Beas, J.; Santa Cruz, J.; Thomsen, P.; Utreras, S. Enseñar a Pensar Para Aprender Mejor; Ediciones Pontificia Universidad Católica De Chile: Santiago, Chile, 2001.

Publisher's Note: MDPI stays neutral with regard to jurisdictional claims in published maps and institutional affiliations.

(C) 2020 by the authors. Licensee MDPI, Basel, Switzerland. This article is an open access article distributed under the terms and conditions of the Creative Commons Attribution (CC BY) license (http://creativecommons.org/licenses/by/4.0/). 